Belezas e mazelas naturais e humanas nas fotografias do livro Bahia de Mario Cravo Neto

Rafael Castanheira

Alexandre Kieling

Artigo recebido em: 29/01/2020

Artigo aprovado em: 08/06/2020 


\title{
Belezas e mazelas naturais e humanas nas fotografias do livro Bahia de Mario Cravo Neto
}

\author{
Natural and human beauties and ailments in the \\ photographs of the book Bahia by Mario Cravo Neto
}

Rafael Castanheira*

Alexandre Kieling**

\begin{abstract}
Resumo: Este artigo se debruça sobre o processo de fotodocumentação de Mario Cravo Neto na cidade de Salvador. Para isso, dedica-se a análise do seu livro Bahia, cuja narrativa volta-se para as belezas e as mazelas das paisagens naturais e humanas desta cidade, com foco na classe trabalhadora de baixa renda. Suas fotografias, realizadas entre os anos 1968 e 1980, não apelam para a estetização da pobreza nem para a representação exótica e pitoresca da capital baiana, e algumas delas se distanciam da ideia de fotografia como espelho do real ao explorar sombras e silhuetas, desfoques e borrões provocados, respectivamente, pela contraluz ou iluminação precária e pelo uso de baixas velocidades do obturador da câmera. O esforço é trabalhar a tensão presente no trabalho de Cravo Neto, especialmente no diálogo que faz com a tradição reformista da "Fotografia Social" e com os fotógrafos ligados à reportagem engajada.
\end{abstract}

Palavras-chave: Fotografia documental. Bahia. Salvador. Mario Cravo Neto.

* Doutor em Comunicação pela Universidade de Brasília. Professor da Universidade Católica de Brasília.

** Doutor em Comunicação pela Universidade do Vale do Rio dos Sinos. Professor da Universidade Católica de Brasília. 
Abstract: This article focuses on Mario Cravo Neto's photodocumentation process in the city of Salvador. To do that, we will target the analysis of his book Bahia, which narrative focuses on the beauty and the ailments of the natural and human landscapes of this city, centered on the low-income working class. Produced between 1968 and 1980, his photographs do not appeal to the aestheticization of poverty nor to the exotic and picturesque representation of the capital city of the State of Bahia, and some of them distance themselves from the idea of photography as a mirror of the reality when exploring shadows and silhouettes, blurs and motion blurs caused, respectively, by backlight or low lightening conditions and the use of low shutter speed. The aim is to work on the tension displayed in the work of Cravo Neto, especially at the dialogue that it makes with the tradition of the "Social Photography" movement and with the photographers attached to the engaged journalism.

Keywords: Documentary Photography. Bahia. Salvador. Mario Cravo Neto.

\section{Introdução}

Mario Cravo Neto nasceu em 1947, na cidade de Salvador, Bahia. Filho do escultor Mario Cravo Junior (1923-2018), ainda muito jovem recebeu dele as primeiras orientações no campo do desenho e da escultura e beneficiou-se do fértil ambiente cultural e artístico da sua casa, onde o seu pai mantinha o ateliê e recebia muitas pessoas como escritores, pintores, fotógrafos, capoeiristas, viajantes etc. Ao longo de mais de quarenta anos da carreira como artista, ele experimentou o desenho, a pintura, a escultura; porém, escolheu a imagem fotográfica como o principal meio para se expressar, envolver-se e documentar o povo baiano e as suas manifestações populares, culturais e religiosas.

Embora a produção dos retratos em preto e branco 
feitos em estúdio, que se estendeu de 1975 até 1999 e resultou na publicação, em 2002, do livro The eternal now (O eterno agora), seja certamente o seu trabalho mais conhecido e o qual the rendeu projeção internacional, Mario Cravo Neto dedicou-se, desde os anos 1970 até pouco antes do seu falecimento em 2009, à documentação fotográfica em cor da sua cidade natal, não apenas dos ambientes sagrados no interior de igrejas e terreiros de candomblé, mas também no ambiente profano das ruas, praças, praias, feiras, mercados, para onde direcionava as suas lentes, principalmente, para as camadas mais pobres da sociedade, compostas de negros e mestiços. Contudo, nessas fotografias, eles nunca aparecem fracos ou infelizes; por vezes cansados, mas sempre altivos e resistentes na rotina de trabalho, ou alegres, extasiados e, às vezes, até violentos nas tradicionais festas religiosas e populares da capital baiana.

Desse modo, o fotógrafo reuniu um acervo de mais de 300 mil imagens com as quais ele realizou várias exposições - incluindo instalações com projetores e som - no Brasil e no exterior, e também publicou mais de vinte livros, ${ }^{1}$ parte deles pela sua própria editora, a Áries. Dessa robusta produção editorial, destacaremos no presente artigo um livro seminal de Mario Cravo Neto que, com a mente, o coração e as lentes fotográficas voltadas para a cultura, a arte e a religião presentes em Salvador da Bahia, traça um panorama visual da vida cotidiana e da arquitetura desta cidade.

Publicado em 1980, o livro Bahia reúne um conjunto de fotografias a capital baiana. São, em sua maioria, registros

1 Dentre eles, destacamos Mario Cravo Neto (CRAVO NETO, 1995), Laróyè (CRAVO NETO, 2000), The eternal now (CRAVO NETO, 2002), O tigre do Dahomey: a serpente de Whydah (CRAVO NETO, 2004) e Butterflies and zebras (CRAVO NETO, 2013). 
das pessoas e das paisagens urbana e natural, que, em linguagem tradicionalmente documental, apresentam os aspectos sociais, culturais e religiosos da cidade. Entretanto, há na obra algumas imagens as quais subvertem o cânone da fotografia de fragmento em quadro do real. Os recortes capturados pela câmera de Cravo Neto se distanciam da ideia de espelho do real, exploram sombras e silhuetas, desfoques e borrões provocados, respectivamente, pela contraluz ou iluminação precária e pelo uso de baixas velocidades do obturador da câmera. Há fotografias com cortes diferenciados que trazem, em alguns casos, pessoas de costas ou ainda objetos inusitados como um cubo de gelo, pinturas na parede etc. São alguns dos aspectos formais que, no começo de sua carreira como fotógrafo, deram pistas do que viria em seus trabalhos futuros.

A discussão no campo da fotografia sobre o discurso social, subjetivo do fotógrafo em relação ao pretendido registro autêntico do flagrante jornalístico ganhou intensidade desde "A Madonna dos cortiços" de Lewis Hine, ${ }^{2}$ que ao fotografar buscando uma composição estética de uma mãe de subúrbio com os três filhos no colo teria promovido uma maneira de revelar realidades sociais. No final dos anos de 1920, as classes sociais menos favorecidas nos Estados Unidos, principalmente imigrantes e operários, tornaram-se o tema por excelência de diversos documentaristas que ficaram conhecidos como concerned photographers. Esta vertente da documentação, cujo preceito básico era o engajamento na luta por melhores condições de vida e trabalho entre as pessoas combinado com uma linguagem simples, sem efeitos pictóricos ou manipulações, será denominada

2 A "Madonna dos cortiços", de Lewis Hine, foi publicada na capa da revista Survey de 8/07/1911. 
de "Fotografia Social" em um texto clássico da história da fotografia escrito em 1909 pelo principal expoente deste grupo, Lewis Hine (1909), para a National Conference of Charities and Corrections sob o título de Social Photography: How the Camera May Help in the Social Uplift (TRACHTENBERG, 1980).

Diante desse contexto, o que pretendemos no presente texto é observar essa tensão no trabalho de Cravo Neto: esse diálogo que ele faz com a tradição reformista da "Fotografia Social" e com os fotógrafos ligados à reportagem engajada sem, no entanto, explorar uma estética da pobreza da qual estes foram alvo de crítica. Não importa aqui entrar no debate conceitual em si. O que se segue é, principalmente, um esforço analítico da narrativa e da estética do fotógrafo baiano, compreendendo, a priori, que seu percurso privilegiou um discurso e uma construção documental diferenciada.

\section{O Livro Bahia}

Bahia, como mencionado, foi o primeiro livro de Mario Cravo Neto, publicado em 1980 pela editora Raízes. A obra, com tiragem de três mil exemplares, formato retangular $(24,5 \times 30,5 \mathrm{~cm})$, saiu em capa dura, inspirada na imagem da Portada do antigo solar José Cerqueira Lima, ilustrada nas cores azul, branco e vermelho, as mesmas da bandeira do estado baiano. Ao todo 108 fotografias coloridas narraram o olhar dele sobre Salvador, entre os anos de 1968 e 1980. Um índice fotográfico apresenta suas legendas, informando do que se tratava cada registro, o local e ano de produção. Além disso, três textos de naturezas distintas buscaram mais introduzir o leitor no contexto cultural e histórico da cidade e do que refletir 
sobre as imagens em si, indicando, assim, o caráter tradicionalmente documental do livro enquanto suporte de registro e memória da capital baiana e do seu povo.

Figura 1- Capa do livro Bahia, 1980.

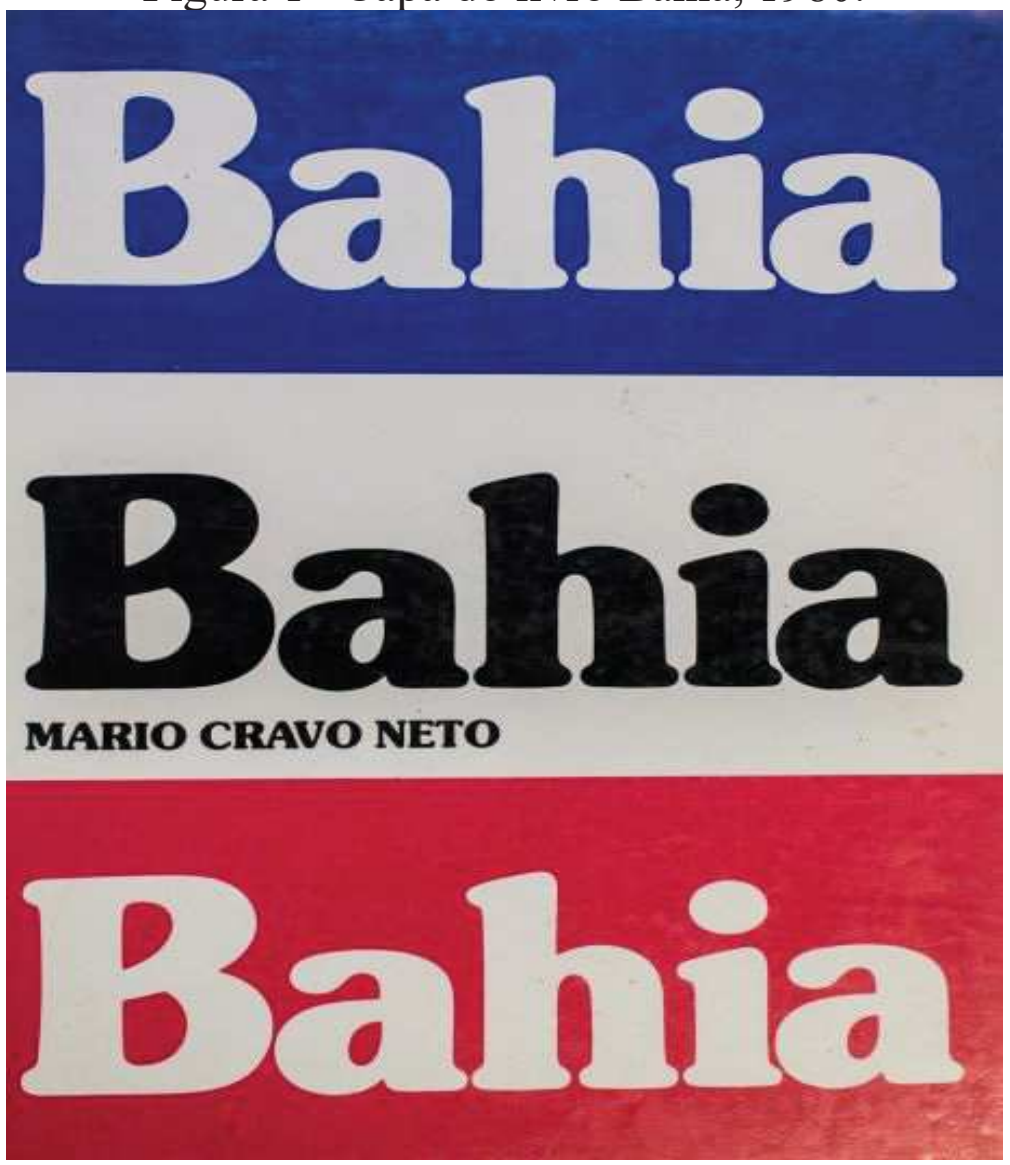

Fonte: Cravo Neto (1980).

Na introdução, Luiz Seráphico (CRAVO NETO, 1980, p. 5), após comentar rapidamente que as fotos de Cravo Neto "expressam na cor, na forma e no movimento o âmago da vida baiana", destaca a importância de as imagens virem acompanhadas do texto épico de Jorge Amado e do estudo de Clarissa Junqueira Coimbra de Cretella no sentido de dar "uma visão da Bahia, história e tradição, a quem não a conhece". Uma visão que, na verdade, se debruça sobre o cotidiano da cidade, apesar de o título sugerir um trabalho 
que englobasse todo o Estado. Bahia é nome compreendido como referência, como síntese do significado dado a essa cidade pelo povo local. Nativos que, ao assim chamá-la, evitam, conscientes ou não, o nome de batismo a ela conferido pelos colonizadores devotos: Cidade do Salvador ou Salvador.

Em Canto de amor à Bahia, Jorge Amado (1980, p. 8) introduz, poeticamente, o leitor na riqueza cultural da cidade "plantada em meio às águas", onde as suas ladeiras, de dia, conduzem ao mar, ao cais do mercado e às feiras com a sua abundância e variedade de comidas e artesanatos e, de noite, aos candomblés com os seus batuques e cantos saudando os santos. Além de descrever a beleza "antiga, sólida e envolvente" da capital baiana, o escritor também exalta o homem "imaginoso, cordial [...] de fala larga, voz cantante e sangue misturado" que nela habita. Em suas frases belas e poéticas, Jorge Amado recita a Bahia como uma "terra mestiça com todos os coloridos do moreno, todas as nuanças entre o branco e o negro", e não deixa de notar que "nem tudo é poesia apenas, e o drama explode nas ruas em enxames de crianças famintas, na multiplicação dos mendigos, na fome em terra tão rica" (idem, p. 9). Assim, nesse texto - originalmente publicado em 1945 como parte do clássico Bahia de todos os santos: guia das ruas e mistérios da cidade de Salvador (AMADO, 1970, p. 157-159), o autor faz um relato apaixonado sobre as belezas e riquezas e, ao mesmo tempo, sobre as mazelas. A escolha da descrição dessa atmosfera de drama e pobreza para abrir o livro Bahia sugere que Cravo Neto já visava, logo de saída, anunciar o tom do discurso imagético nele adotado: uma mistura de homenagem poética à sua cidade natal e sua gente 
com crítica social da sua realidade nos anos $1970 .^{3}$

Outra curiosa intencionalidade pode ser observada após a narrativa fotográfica da obra. $\mathrm{O}$ último texto do livro vem contextualizar historicamente as imagens antes observadas pelo espectador. A Bahia tem um jeito que nenhuma terra tem, escrito por Clarissa Coimbra de Cretella (1980), trouxe caráter essencialmente informativo e explicativo, e está dividido em três tópicos que tratam, didaticamente, da história da primeira capital do Brasil, da sua tradição barroca, externada na arquitetura civil e religiosa dos primeiros casarões, fortes e igrejas do país e, finalmente, do seu sincretismo caracterizado pela mistura de elementos culturais oriundos da Europa cristã, dos diferentes povos africanos aqui escravizados e da população ameríndia.

É, portanto, desse caldeirão multicultural repleto de paradoxos, onde convivem, lado a lado, sofrimento e beleza, fome e fartura, opressão e resistência, antiguidade e modernidade, artes, crenças e tradições diversas, que Mario Cravo Neto vai extrair a matéria-prima para construir a sua Bahia, não apenas nesse, mas em quase todos os seus livros.

3 De acordo com o índice fotográfico apresentado no livro, a maioria das fotografias foram produzidas na segunda metade da década de 1970, havendo algumas produzidas em 1974 e apenas uma em 1968. E elas serão aqui apresentadas tal como nas legendas desse índice. A única foto que não é, portanto, da década de 1970, mostra uma mulher com uma ferramenta em uma ruína e tem o título de "Invasão, Ondina" - o que dá a ideia da importância do tema social para o autor das fotos já que ele fez questão de resgatar algo que não se refere a um tema turístico. 


\section{A narrativa}

A sequência de fotografias do livro foi iniciada com o registro de uma pintura popular na qual se vê, ao centro, a galé “Gratidão do Povo 1892”, principal embarcação de uma das mais tradicionais festas da cidade. A Festa do Nosso Senhor dos Navegantes, realizada entre os dias 31 de dezembro e $1^{\circ}$ de janeiro, tem origem portuguesa e, em Salvador, envolve a procissão marítima de centenas de embarcações que acompanham essa pequena galé em sua condução, pela Baía de Todos-os-Santos, da imagem da Nossa Senhora da Conceição, concepção da Virgem Maria, que é tida como protetora dos navegantes contra os perigos do mar. Precedido por três dias de orações e missa solene, o evento acaba em festa do largo, transformando-se em um verdadeiro réveillon popular. Portanto, essa fotografia e a que a ela sucede na abertura de Bahia - na qual uma vista bucólica da praia de Itapuã ao amanhecer exibe também o mar, nesse caso, com nove canoeiros remando em águas tranquilas (Figuras 2 e 3) - não apenas sugerem a profunda relação da cidade com o oceano, como também, vistas em sequência, apresentam os primeiros laços culturais e religiosos de sua gente formada pela mistura de europeus, africanos e indígenas. As diferenças entre as embarcações representadas na pintura e na foto (a galé historicamente usada no mar Mediterrâneo e a canoa ou "piroga" tradicionalmente indígena) já denotam as distintas raízes das quais surgiram o povo brasileiro. E o sincretismo religioso afro-baiano se evidencia na figura da Virgem Maria também identificada como Iemanjá - orixá feminino do panteão africano que reina no mar - santidades para o catolicismo e para o candomblé. 
Figura 2 - Mario Cravo Neto. Procissão do Nosso senhor dos Navegantes, Boa viagem, 1980

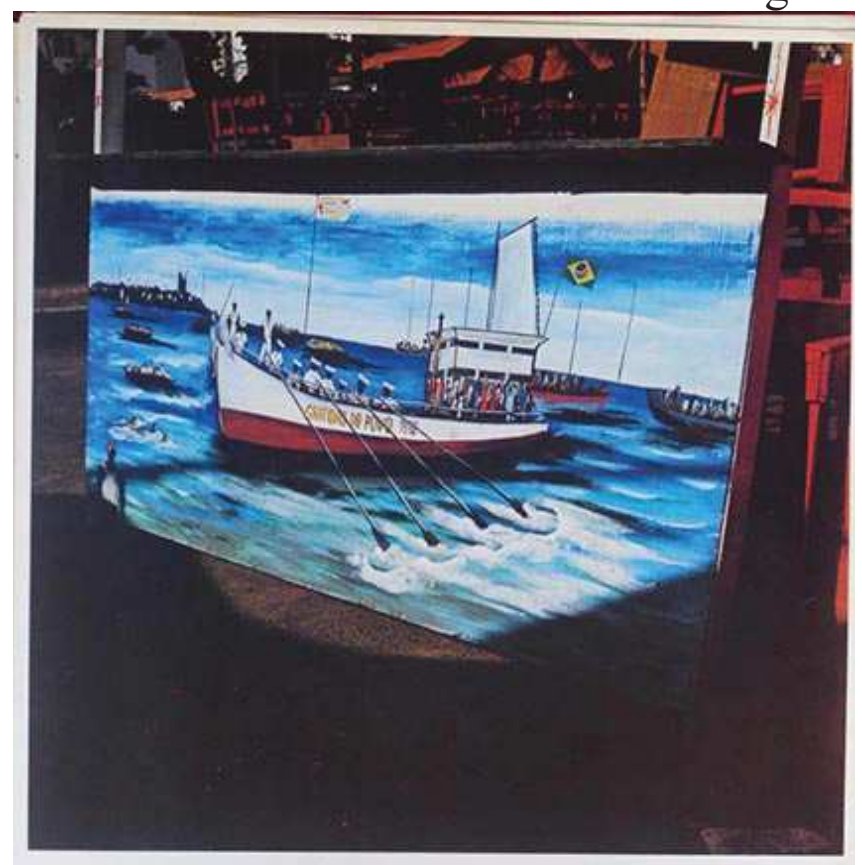

Fonte: Cravo Neto (1980).

Figura 3 - Mario Cravo Neto. Canoeiros, Itapuã, 1979.

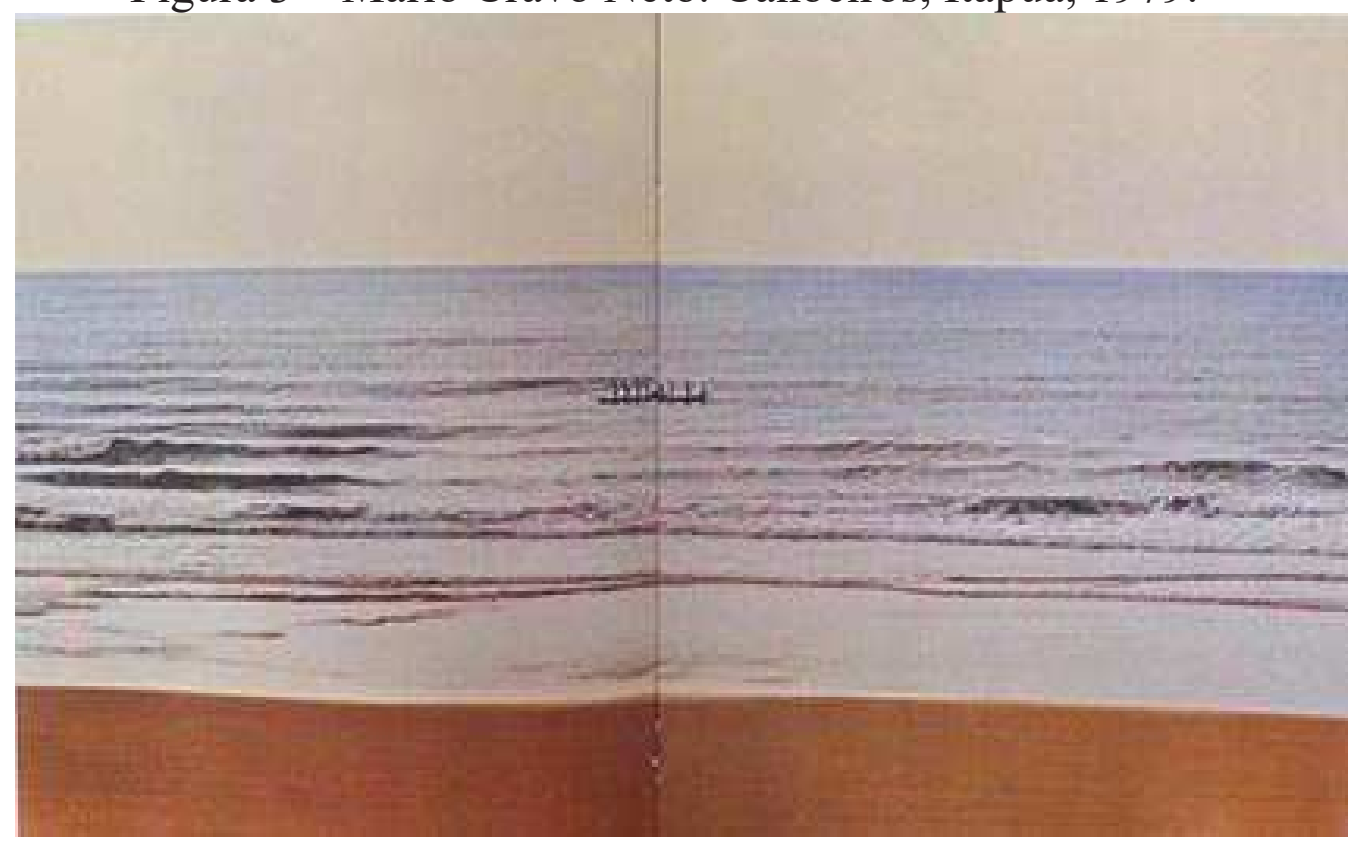

Fonte: Cravo Neto (1980).

As referências a Iemanjá e à própria relação do povo baiano com as águas permanecem explícitas e ininterruptas pelas doze 
páginas seguintes e no final do livro. Nelas, observamos fotografias das lavadeiras da Lagoa do Abaeté, em Itapuã, dos saveiros e das emblemáticas jangadas de pescadores atracadas na praia de Amaralina ou no cais da Feira de São Joaquim e, notadamente, das baianas em trajes típicos com as suas oferendas destinadas à Santa.

As mulheres predominam nessas imagens iniciais que, se, em casos isolados, mostram-nas entrecortadas (Fig. 4), em muitos outros elas aparecem - tal como a maioria dos personagens do livro - retratadas tradicionalmente em planos médios ou mais abertos, contextualizando-as no seu ambiente de trabalho ou de festejo (na lagoa, no mar ou em terra firme). Se o sujeito da ação é essência para a narrativa documental, para Cravo Neto o contexto e o espaço da cena também o são.

$\mathrm{Na}$ fotografia abaixo (Fig. 5), uma baiana, tipicamente vestida com bata branca, turbante, brincos, colares, braceletes, pulseiras e balangandãs, fita o fotógrafo e a lente com a simpatia e a alegria de uma devota que se orgulha em homenagear Iemanjá neste que parece ser o dia da sua maior festa, celebrada sempre no dia dois de fevereiro. 
Figura 4 - Mario Cravo Neto. Lagoa de Abaeté, Itapuã, 1979.

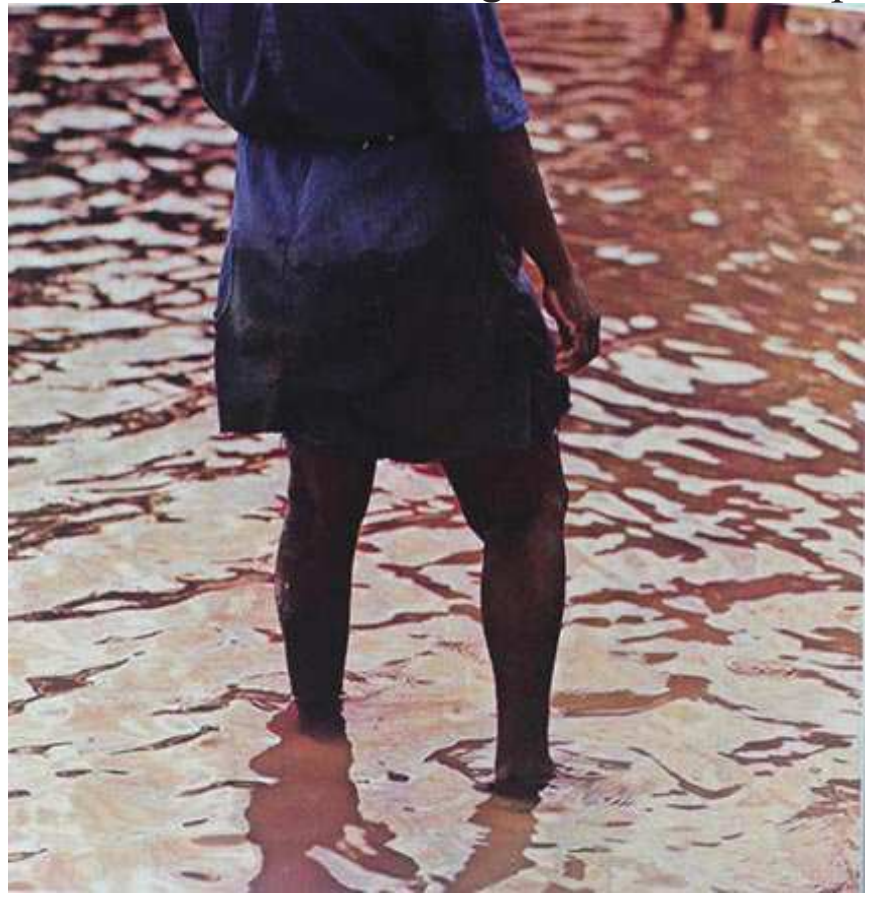

Fonte: Cravo Neto (1980).

Figura 5 - Mario Cravo Neto. Baiana, Rio vermelho, 1979.

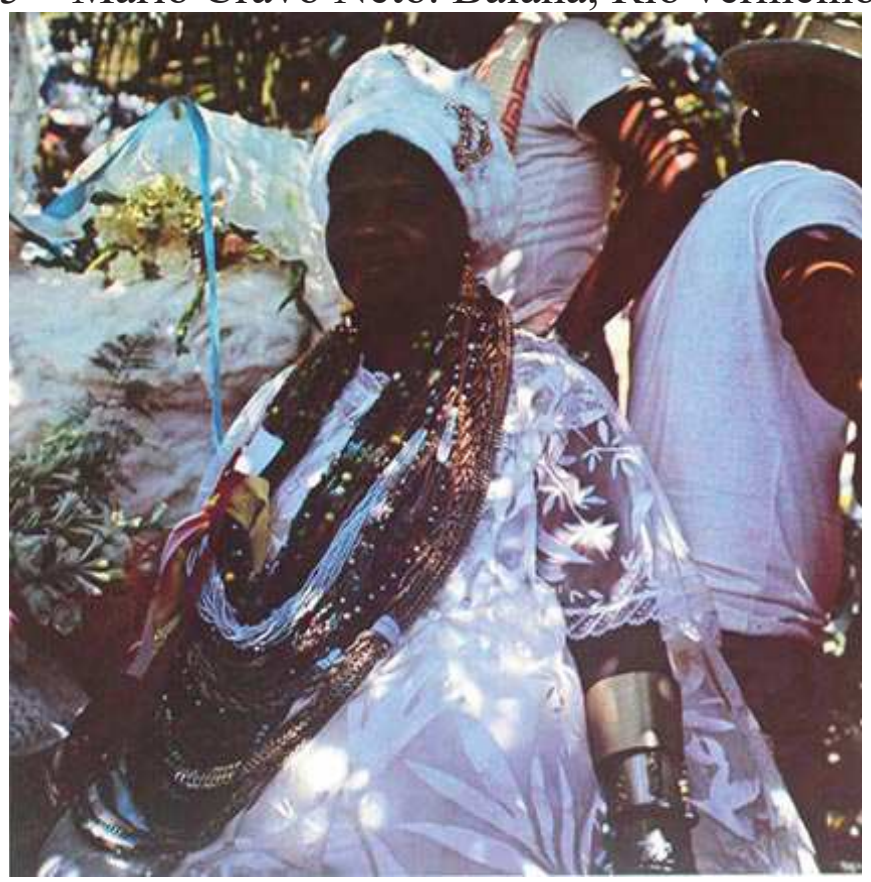

Fonte: Cravo Neto (1980).

Um grupo de fotografias que segue sugere uma sequência de flagrantes da Festa de Iemanjá. Uma das mais populares do ano, 
ela reúne, principalmente na praia do Rio Vermelho, uma multidão de pessoas de todas as origens e de todos os meios sociais, que vêm homenagear a Mãe das Águas. Em revência ao mítico da natureza vaidosa da Santa, trazem-lhe diversas oferendas, tais como ramos de folhas frescas ou artificiais, frascos de perfumes, sabonetes, pentes, espelhos, cortes de tecido etc. Crentes do poder de Iemanjá sobre as águas, muitas esposas de pescadores, que vivem a angústia da espera pelo retorno dos maridos, a juntam às oferendas "demandas" que são pedidos e súplicas expressas em cartas, pulseiras, colares e até dinheiro. Tudo é transformado em imensas corbelhas floridas, as quais são levadas em procissão até a praia, onde os atabaques animam os fiéis. De lá, eles seguem em saveiros, barcos ou lanchas a motor para lançar esses balaios de presentes ao mar.

É esse contexto que não escapa ao olhar de Cravo Neto que, ao trabalhar junto a Emanoel Araújo e Carlos Gordilho, no projeto editorial e na sequência das imagens, justapôs, por vezes, um conjunto de quatro a fim de que, em página dupla, as imagens operem estética e funcionalmente para transmitir uma realidade sobre a relação entre Iemanjá e seus devotos. Uma realidade se conecta com a festa e as crenças em torno da divindade. Reza a tradição que os presentes, uma vez depositados ao mar, devem mergulhar até o fundo, um sinal da aprovação de Iemanjá. Em contrário, se boiarem e forem devolvidos à praia, é sinal de recusa, para grande tristeza e decepção dos admiradores da divindade (VERGER, 2002, p. 193). No jogo de fotos abaixo, as duas situações foram evidenciadas. 
Figura 6 - Mario Cravo Neto. Presente para Iemanjá, Rio Vermelho, 1978.
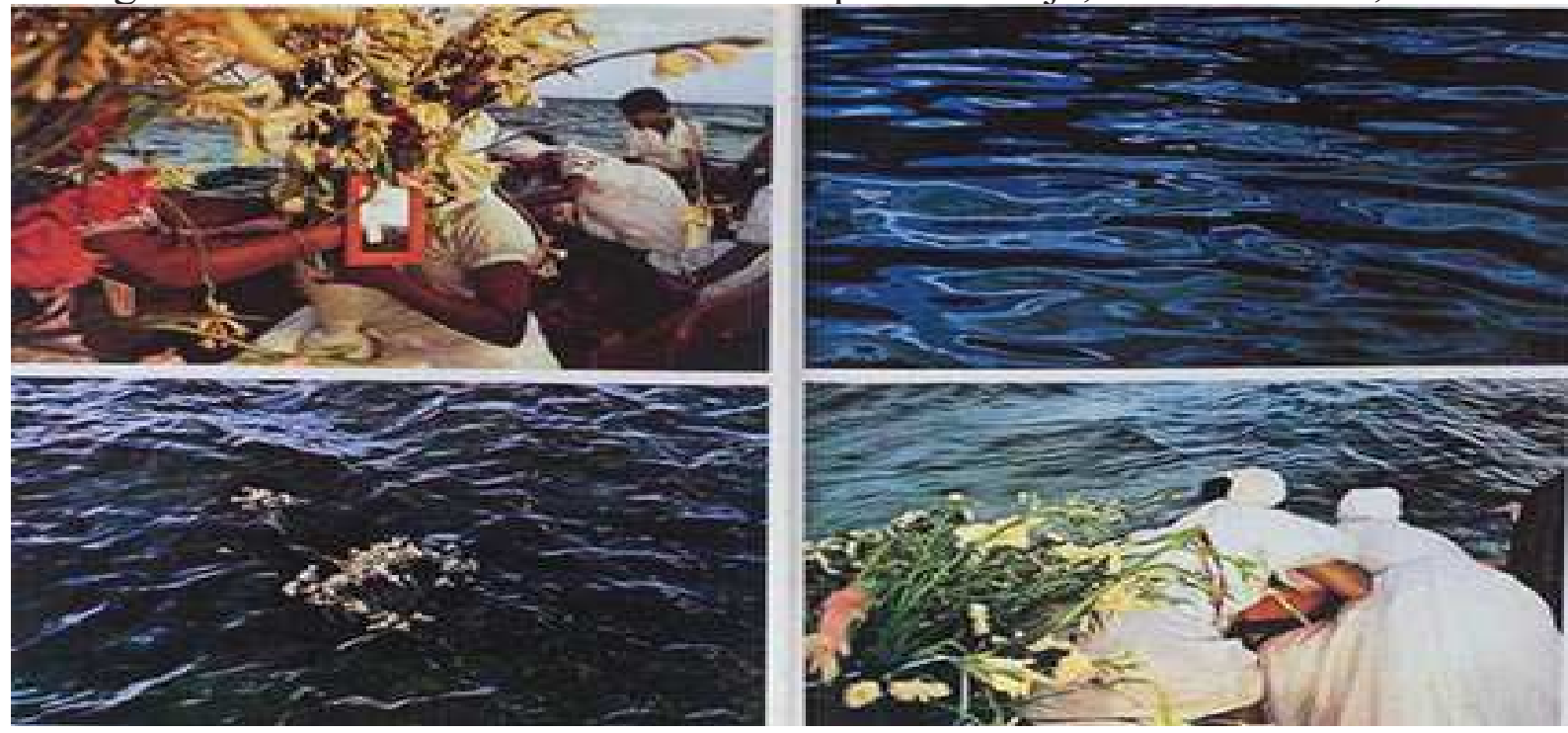

Fonte: Cravo Neto (1980).

\section{O discurso}

A narrativa fotográfica do livro se concentra essencialmente no povo baiano e na sua relação com a cidade, extraindo dele e do seu cotidiano a carga informativa, cultural e, muitas vezes, poética necessária para a construção do livro. Afinal, como já dizia Jorge Amado (1970, p. 15), “aqui toda a cultura nasce do povo, poderoso na Bahia é o povo, dele se alimentam artistas e escritores. [...] Essa ligação com o povo e com os seus problemas é a marca fundamental da cultura baiana". Mario Cravo Neto, como um bom filho da terra, sabia disso e direcionou as suas lentes não para a população da classe alta, nem para a burguesia abastada, mas, sim, para a gente das camadas economicamente limitadas ou com nenhum recurso, como feirantes, ambulantes, pequenos comerciantes, sacerdotes do candomblé, meninos de rua. Enfim, moradores de bairros populares e transeuntes eram retratados durante as incursões do fotógrafo pelas regiões mais desassistidas de Salvador, bem como para o interior de 
130 Belezas e mazelas naturais e humanas nas fotografias do livro Bahia de Mario Cravo Neto

igrejas e terreiros de candomblé.

Nos anos 1970 o Pelourinho, bairro histórico da cidade, viveu um período decadente, tanto de degradação social e do seu patrimônio arquitetônico, marcado pela pobreza, violência e prostituição, quanto pela má conservação de suas igrejas e casarões coloniais. Apesar disso, Cravo Neto não fotografou o bairro e os seus moradores (ou frequentadores) pelo viés da denúncia do descaso público por aquele ambiente que o rodeava. Ele procurou, por outro lado, retratá-lo com um lirismo próprio que caracterizaria, desde então, o seu olhar sobre os assuntos locais e os seus conterrâneos. Profundo conhecedor da cidade, Cravo Neto enxergava beleza e originalidade nas cenas simples, singelas, por vezes tristes, da cidade e dos seus habitantes.

Figura 7 - Mario Cravo Neto. Barbearia e Dominó, Pelourinho,1980.
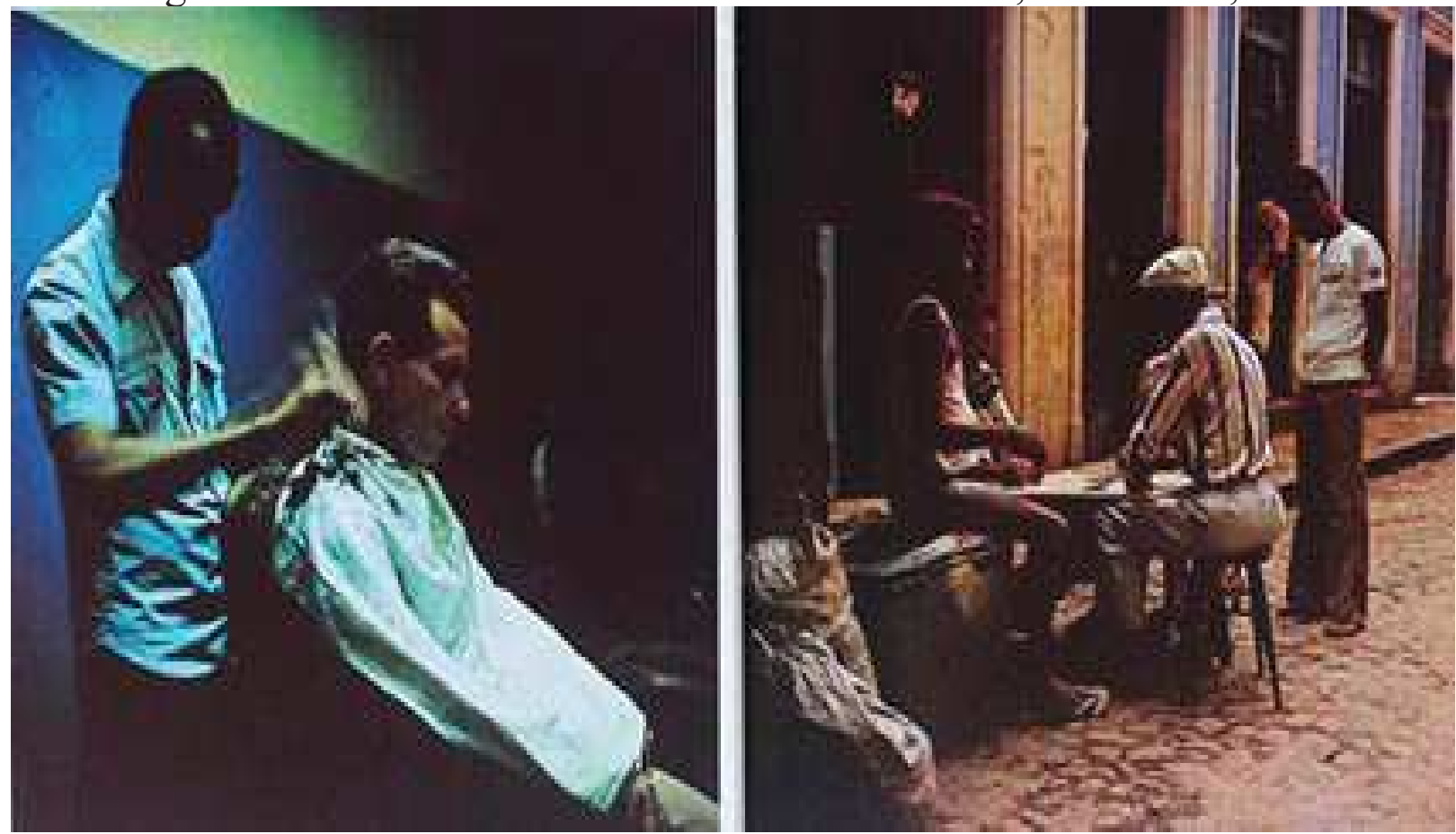

Fonte: Cravo Neto (1980).

Ainda que os personagens dessas duas fotografias acima 
pareçam desavisados da presença do fotógrafo, elas não poderiam ser consideradas exatamente flagrantes no sentido de revelar alguma verdade ou de representar um momento incomum ou espetacular da vida dos retratados. O que verificamos nelas, bem como na maioria das imagens do livro, são registros de situações corriqueiras que, justamente pela sua banalidade, exibem a singularidade do povo baiano na sua relação com o tempo. Justapostas nas páginas de Bahia, elas parecem querer falar sobre um tempo que corre mais lentamente, seja no movimento evidenciado pelo leve borrado da mão com a tesoura do atento barbeiro que apara cuidadosamente os cabelos de seu cliente, seja pela aparente despreocupação dos jogadores de dominó com os possíveis horários e compromissos profissionais típicos dos grandes centros urbanos (as fotos são de 1980).

Com um tabuleiro apoiado sobre as suas pernas a lhes servir como mesa e até um baú-lixeira como assento para um deles, esses jogadores se organizam improvisadamente para se divertir em "uma cidade onde se conversa muito. Onde o tempo ainda não adquiriu a velocidade alucinante das cidades do Sul” (AMADO, 1970, p. 14). Além disso, não há como ignorar que, se na imagem à esquerda um negro, o barbeiro, trabalha para um branco, o cliente, cortando o seu cabelo, na foto ao lado, os personagens de ambas as cores se divertem no jogo. A justaposição destas fotos - certamente não arbitrária - sugere assim que as diferenças entre classes e raças não impedem, por vezes, a mistura e a convivência nos momentos de lazer e diversão.

Viver sob um ritmo mais lento, como notou Jorge Amado, não quer dizer, em absoluto, que o povo baiano não tenha uma história de trabalho duro, assim como de luta e resistência para enfrentar as 
desigualdades sociais, a opressão e o preconceito que perduram em Salvador desde a sua fundação até os dias atuais. Nesse sentido, se as paisagens naturais e urbanas da capital baiana e as ocasiões de festas e diversão se encontram representadas no livro, é também verdade que nele a vida do trabalhador em sua lida diária é não apenas mostrada, mas, sobretudo, enaltecida por Cravo Neto, por meio de retratos realizados nas feiras, mercados e praças da cidade.

Figura 8 - Mario Cravo Neto. Verdureiro, 1979 e Vendedora de Acarajé, 1978.
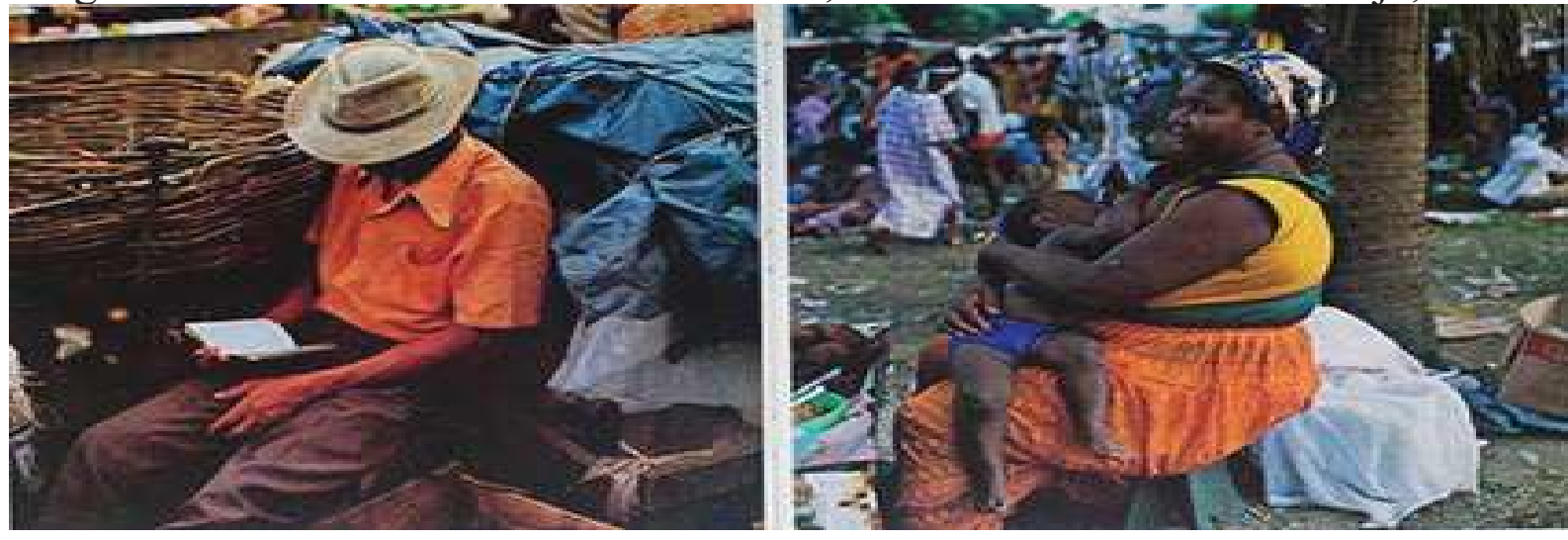

Fonte: Cravo Neto (1980).

O Verdureiro da Feira de São Joaquim e a Vendedora de Acarajé do Campo Grande (Fig. 8) são exemplos de imagens em que percebemos mais facilmente o olhar respeitoso com o qual Cravo Neto observava a sua gente trabalhadora. Ambos os personagens são fotografados em planos médios os quais captam a quase totalidade de seus corpos e alguns elementos do seu entorno, nos possibilitando analisar parte do contexto no qual eles estão inseridos. A alma do sujeito e o contexto do objeto sugerem um recorrente tom no discurso social do fotógrafo. Ao mesmo tempo em que mostra aquela realidade objetiva, subjetiva seu sentido na harmonia observável pelo ambiente. As condições são modestas, e até de certa forma precárias, 
mas não há um caráter de denúncia no olhar do fotógrafo.

Sentado ao lado de um caixote e um balaio de vime quase vazio, o verdureiro, elegantemente vestido em roupa social e chapéu de pano, dedica-se à leitura de um livro. $\mathrm{O}$ seu horário de trabalho parece ter se encerrado, já que a sua provável banca de verduras se encontra fechada, coberta em lona plástica e cordas. É nesse momento então que esse homem, após ter realizado o seu serviço, volta-se às orações ou ao conhecimento formal, extraído da bíblia ou de algum outro livro, uma atitude tão serena e louvável quanto à da vendedora de acarajés da imagem ao lado. Ela, por sua vez, não poderia ter sido registrada em momento mais sublime, marcado por uma ação duplamente elogiável: ao mesmo tempo em que cuida de sua banca de acarajés, amamenta o filho em seu colo. Ademais, as feridas e cicatrizes visíveis na pele de seus corpos são marcas da vida difícil que levam e na qual as intempéries são resolvidas com perseverança e trabalho, como a imagem indica.

Esse olhar reverente de Cravo Neto para com o outro é ainda mais evidenciado pelas imagens de personagens que exercem profissões estigmatizadas ou que se encontram em situações complicadas de moradia. Em uma delas, uma prostituta é retratada no Pelourinho em pose espontânea, momento no qual, provavelmente surpresa com a presença da câmera, sorri para o fotógrafo (Fig. 9). Além de parecer não se importar em ter os seus seios visíveis devido à translucidez do seu vestido, em seu pescoço ela leva um colar com o amuleto em forma de um punho cerrado ou em figa, demonstrando a sua altivez e crença neste símbolo de resistência ou contra a inveja e mau-olhado. 
134 Belezas e mazelas naturais e humanas nas fotografias do livro Bahia de Mario Cravo Neto

Figura 9 - Mario Cravo Neto. Mulher da vida, Pelourinho, 1980.

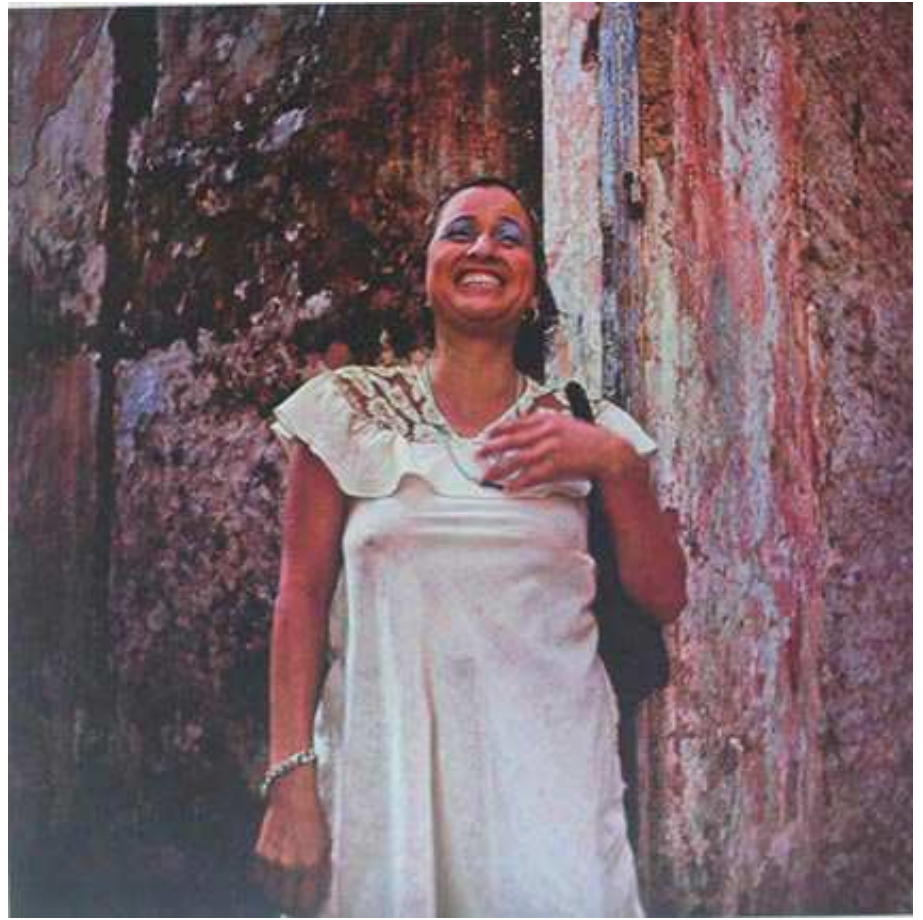

Fonte: Cravo Neto (1980).

Figura 10 - Mario Cravo Neto. Invasão, Ondina, 1968.

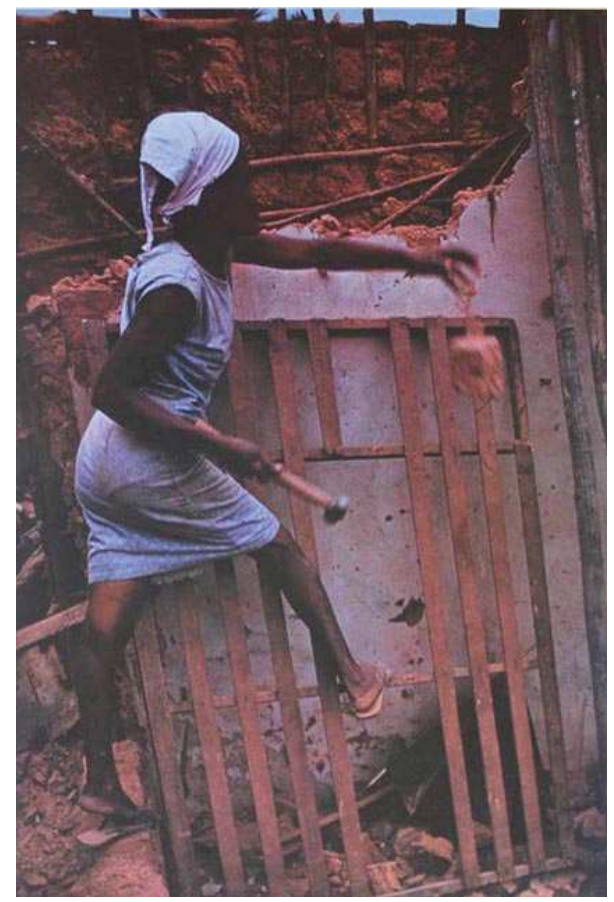

Fonte: Cravo Neto (1980).

Já em um outro retrato, a figura feminina é, mais uma vez, valorizada por Cravo Neto, que a registrou durante um trabalho duro 
e mais comumente realizado por homens (Fig. 10). Em meio aos escombros de uma antiga edificação e com uma pequena marreta nas mãos, uma mulher negra derruba uma parede em um terreno invadido no bairro de Ondina, como a legenda da imagem nos confirma. Notamos ainda um muro de pau-a-pique ao fundo da imagem, sugerindo que uma nova residência, bem mais simples, tenha sido ali construída à revelia, obviamente, das normas legais do Estado. Dessa forma, o fotógrafo empoderou socialmente tanto a figura da prostituta quanto a da invasora de terrenos ao captálas, respectivamente, em condições de honradez e trabalho pesado, independentemente da "imoralidade" e ilegalidade da atividade que exercem.

Segundo Jorge Amado (1970, p. 37), as invasões de terrenos e o surgimento de bairros operários e populares em Salvador começaram nos anos 1940. A partir dessa época, a cidade rica cresceu para o lado do mar, onde colinas eram rasgadas e novas ruas eram abertas e asfaltadas, gerando especulação imobiliária. Aos pobres, porém, isso não aconteceu. Quanto a estes, destaca o escritor, apenas "houve barulho, houve cadeia, houve tiro, gente presa e muita luta". Contudo, apesar desse passado - e também presente - violento, de confronto e resistência, Stefania Brill (1986, p. 27), em conversa com Mario Cravo Neto sobre o seu trabalho, faz uma importante observação: "Pensando bem, nunca vi violência alguma em suas fotos, no entanto ela existe". O discurso fotográfico do baiano mostra sem sublinhar. Enuncia sem gritar. 


\section{A dialogia e a fuga}

Mesmo documentando a classe trabalhadora de baixa renda, tema que o faz dialogar diretamente com a tradição dos fotógrafos pioneiros desta corrente reformista chamada nos Estados Unidos de "Social Photography" (Fotografia Social) e também do fotojornalismo engajado que se desenvolveu ao longo do século XX, Mario Cravo Neto não apela, entretanto, para a estetização do sofrimento tampouco para o exotismo das temáticas populares e quase sempre afro-brasileiras dos seus trabalhos. As suas documentações fotográficas, realizadas entre os anos de 1970 e 2000, diferem-se não apenas das pinturas e relatos românticos e bucólicos dos primeiros viajantes pelas terras brasileiras, mas também das imagens do fotojornalismo e da publicidade produzidas nessa época no Brasil. Sobre este aspecto, Herkenhoff (1994, p. 49) nota que, em Salvador, "a presença das tradições africanas se mantém com intenso vigor", e o olhar de Cravo Neto, "mesmo sem perder a dimensão étnica, reage contra a folclorização desse universo cultural popular muito comum na pintura e na literatura".

Assim, mantendo uma visão positiva diante das condições, muitas vezes, precárias dos seus personagens, Cravo Neto documenta a população negra e, geralmente, pobre de Salvador, sem romantizar nem denunciar diretamente a sua realidade de opressão e violência que, com certeza, existe. $O$ fotógrafo, diante da observação de Brill já mencionada, até admite que, "às vezes, gostaria de fazer imagens de violência, só que não a vejo muito, passo por ela". A violência, porém, não lhe é indiferente. Ele apenas a enxerga de outra forma: "Violento, para mim, nunca é um cadáver em si. Violência é incompetência, 
omissão, indiferença, estupidez ou uma simples falta de respeito para com o ser humano" (CRAVO NETO apud BRIL, 1986, p. 27).

De fato, esta forma de violência oriunda da incompetência, omissão e estupidez não precisa, necessariamente, ser representada com cadáveres. Observamos uma preocupação com aquele ambiente social, mas uma clara fuga da acentuação do drama e da tragédia. A vulnerabilidade está lá, todavia o que lhe importa é a resiliência. A fotografia a seguir (Fig. 11), realizada em uma das ruas antigas e malconservadas durante o carnaval de 1980 no Pelourinho, referenda o discurso de seu autor. Por um lado, ela não esconde a fragilidade da vida de pessoas que, sem condições econômicas, de moradia e de educação adequadas, podem ser levadas ao abandono nas ruas ou ao alcoolismo, como sugere a figura de um homem deitado (talvez de ressaca) na calçada. Por outro lado, ainda que esse personagem, pelo seu local e condição de estar no mundo, chame a atenção do espectador mais fortemente para si do que para o resto da imagem, o fotógrafo teve o cuidado de escolher um enquadramento e uma composição suficientemente capazes de mostrar o contexto familiar e de festa (e não de morte) que denotam, respectivamente, a criança sentada em uma cadeira próxima a ele na porta de uma casa, e as bandeirolas coloridas cruzando a rua, amenizando assim aquele que, sem elas, seria somente um cenário de tristeza e desolação. 
138 Belezas e mazelas naturais e humanas nas fotografias do livro Bahia de Mario Cravo Neto

Figura 11 - Mario Cravo Neto. Carnaval, Pelourinho, 1978.

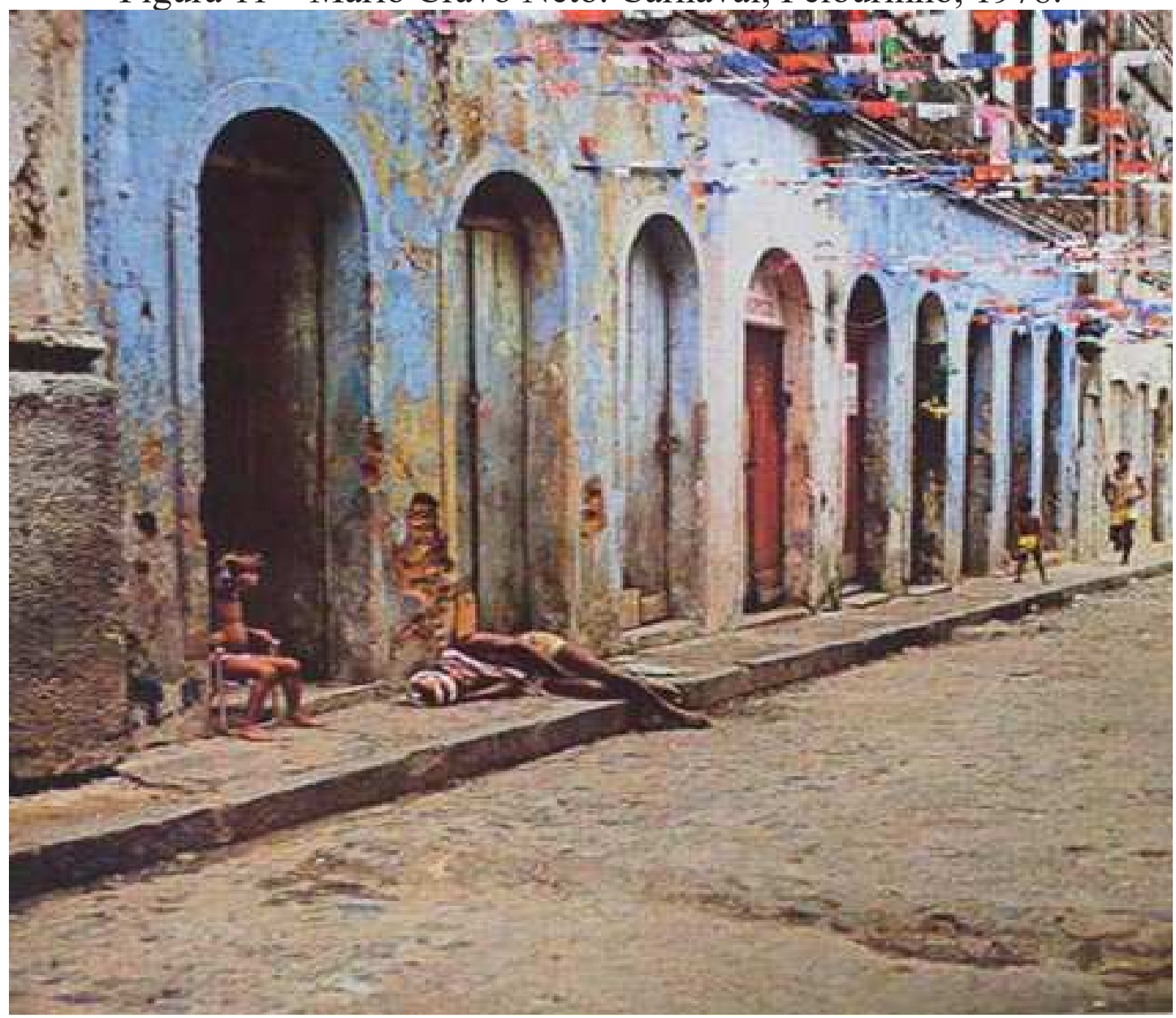

Fonte: Cravo Neto (1980).

Diante dos últimos retratos apresentados acima, é possível perceber que o engajamento social na obra de Mario Cravo Neto não se mostra pela espetacularização das mazelas humanas nem pela indiferença a elas. Sua indignação frente às desigualdades não se dá pela exposição crua e, por vezes, vulgar das condições precárias de vida da população pobre da sua terra, mas aparece mais precisamente na sua maneira de documentá-la franca e poeticamente, transformando-a em símbolo de força e resistência do povo. Talvez essa seja uma de suas estratégias para enfrentar as representações estereotipadas a respeito do povo baiano e, principalmente, da população afrodescendente e as suas religiões na Bahia. 


\section{O não aleatório}

Algumas das imagens de Bahia parecem que, mais do que expressar uma interpretação poética de Mario Cravo Neto sobre Salvador e a sua gente, são usadas no livro em caráter ilustrativo, no sentido de descrever objetivamente certos elementos que caracterizariam a cidade. É o caso, por exemplo, de alguns conjuntos de quatro imagens em página dupla que apresentam registros figurativos, quase catalográficos, de utensílios domésticos, frutas e outros produtos típicos da região, encontrados pelo fotógrafo na tradicional Feira de São Joaquim. Há também fotografias de bancas de venda de miudezas, quinquilharias e produtos variados e ainda, de forma até mesmo redundante, outros retratos de vendedoras de acarajé, o que transforma essa parte central do livro em uma espécie de glossário de objetos e tipos sociais que Cravo Neto, em sua primeira empreitada editorial, teria escolhido para, resumidamente, definir a rica cultura do povo baiano com ênfase na sua classe trabalhadora.

Figura 12 - Mario Cravo Neto. Frutas - Cerâmica, Feira de São Joaquim, 1977.
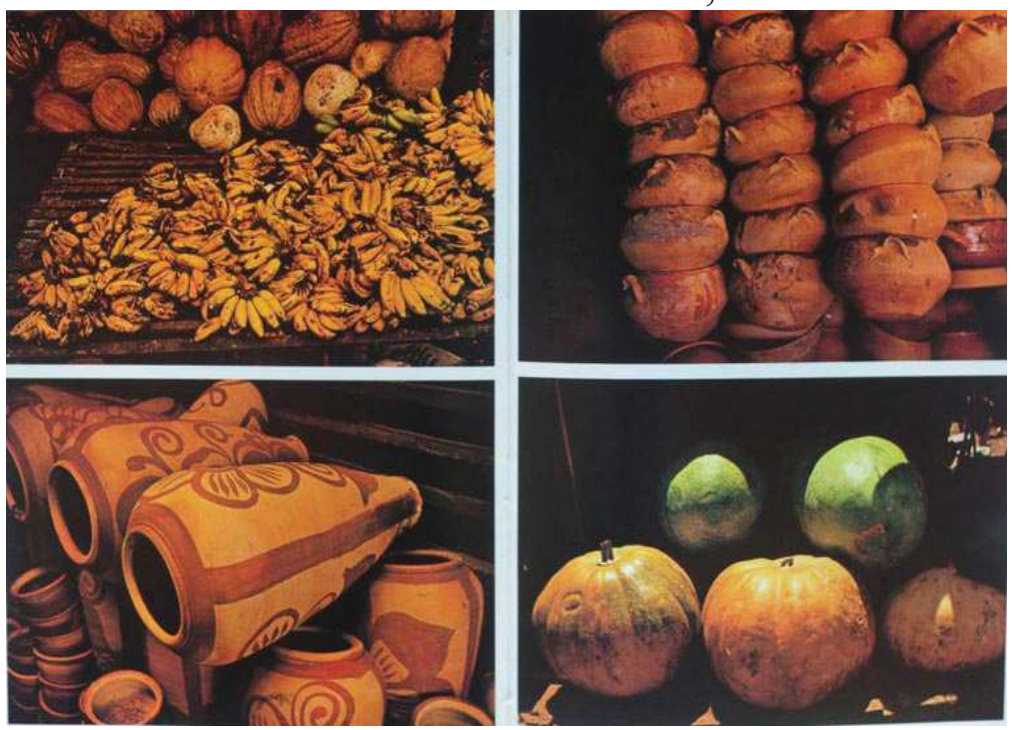

Fonte: Cravo Neto (1980). 
Figura 13 - Mario Cravo Neto. Colher de pau - Jogo de dama, 1980 e Baiana - Bucha, Feira de São Joaquim, 1978.
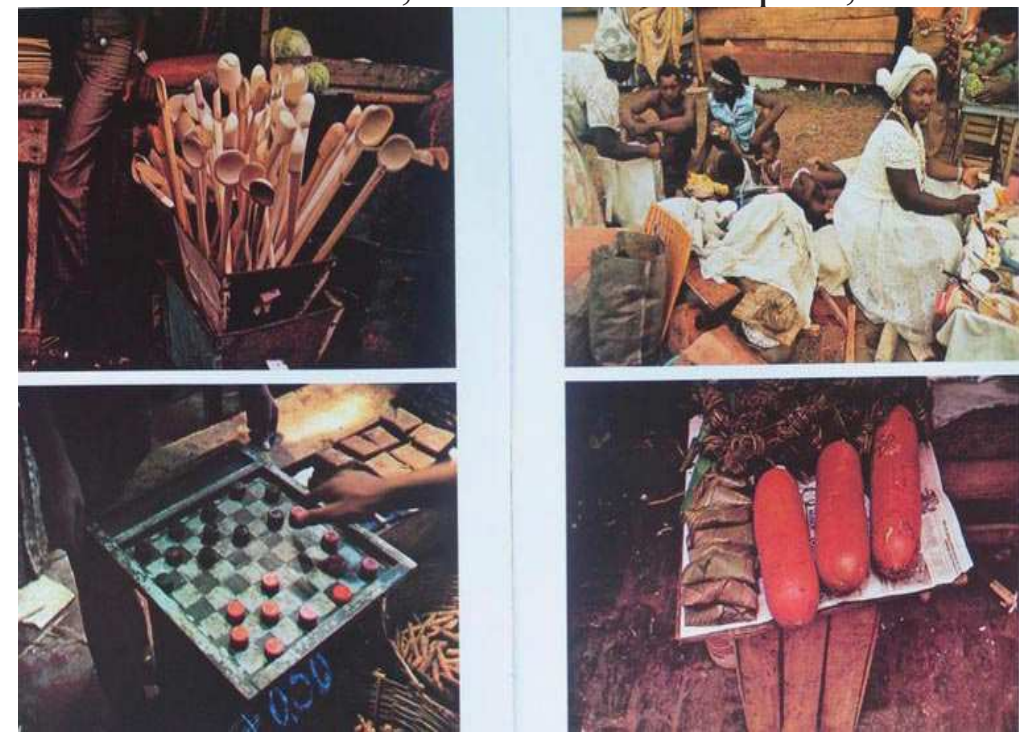

Fonte: Cravo Neto (1980).

Contudo, a representação não totalmente figurativa não é ao acaso. Nada é aleatório. Trata-se de outro aspecto de algumas fotografias de Cravo Neto que não apenas destoa da objetividade desses registros acima, como também questiona as associações historicamente estabelecidas entre esse medium e o conceito de "espelho do real", distanciando, por conseguinte, o trabalho do fotógrafo baiano das práticas mais tradicionais do fotojornalismo e da documentação fotográfica amparada na anunciada objetividade. Mario Cravo Neto sugere querer documentar, mas é deliberadamente subjetivo. Utiliza simultaneamente as baixas velocidades do obturador e o movimento da câmera na produção de algumas imagens de personagens e também de paisagens urbanas do livro Bahia.

Uma delas exibe a fachada da Igreja do Bonfim decorada com uma enorme quantidade de lâmpadas para uma provável comemoração natalina (Fig. 14). Ao fotografar a mais famosa igreja de Salvador em contra-plongé durante a noite, momento em que a 
ausência de luz natural demanda, em geral, o uso de longos tempos de exposição do filme, Cravo Neto, optando ainda por um leve movimento da câmera, transforma a igreja em pura poesia religiosa, em detrimento do registro objetivo de seus traços e detalhes arquitetônicos que permitiriam mais facilmente a sua identificação.

Figura 14 - Mario Cravo Neto. Igreja do Bonfim, Bonfim, 1975.

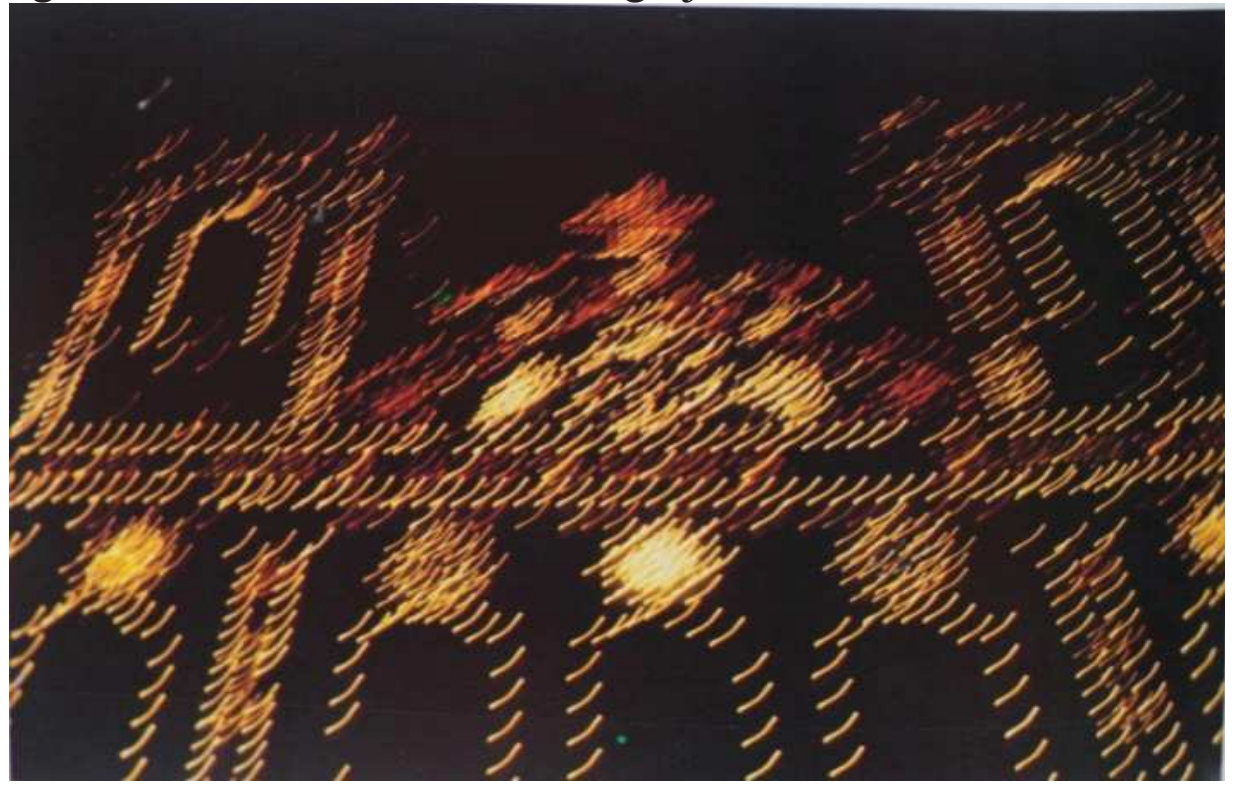

Fonte: Cravo Neto (1980).

Figura 15 - Mario Cravo Neto. Filha de Santo, Boca do Rio, 1974.

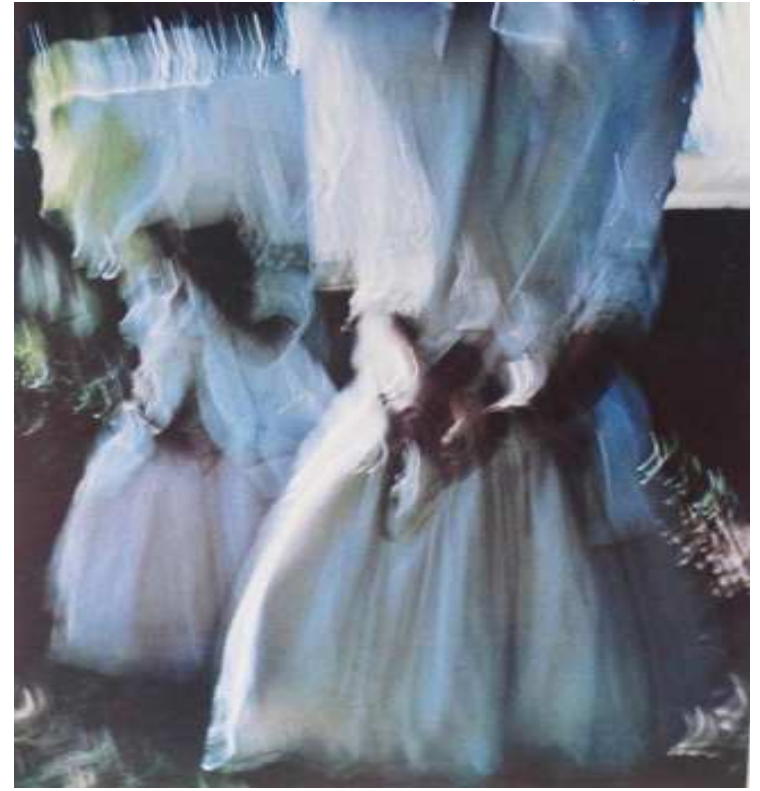

Fonte: Cravo Neto (1980). 
Em uma outra fotografia desse grupo experimental (Fig. 15) mostrada em outra parte do livro e realizada no bairro da Boca do Rio, provavelmente durante uma cerimônia em um terreiro de candomblé, mal conseguimos identificar as filhas de santo devido aos efeitos provocados pelos seus movimentos somados, novamente, ao deslocamento da câmera e à baixa velocidade de obturador durante o registro da cena. Nessa situação, as tradicionais vestimentas dessas mulheres se tornam, na imagem, apenas manchas brancas a contrastar com outras manchas escuras menores que são parte de seus braços e rostos borrados. Além disso, a atmosfera de beleza e mistério na fotografia é ainda mais reforçada pelos brilhos oriundos dos reflexos da luz sobre as suas pulseiras de prata e outros elementos nos vestidos das filhas de santo que, com o movimento dos seus corpos, convertem-se em raios luminosos, indicando, talvez, o desejo de Cravo Neto de externar a sua visão sobre os mistérios que cercam uma religião esotérica como o candomblé.

\section{A segunda camada}

O oculto não fala, não aparece na foto, mas está nas crenças exotéricas. $\mathrm{O}$ fotógrafo baiano se desafiou em buscar esses mistérios, procurando revelar o invisível em uma segunda camada dos seus quadros.

O candomblé originou-se na diáspora de diferentes povos africanos escravizados, formando-se e transformando-se no contexto social e cultural católico do Brasil do século XIX. Estabelecido na clandestinidade, já que por aqui as tensões seculares do sistema escravagista e o poder absoluto do catolicismo poderiam ter levado 
a sua extinção, o candomblé, para sobreviver, teve que adotar características regionais, o que o torna uma religião brasileira: o próprio termo candomblé se referia, primeiramente, às danças e aos atabaques dos escravos nas fazendas do país e, por extensão, passou a designar as cerimônias religiosa dos negros (BASTIDE, 1978; CAMARGO, 2010; CARNEIRO, 1977; PRANDI, 2005, 2009).

O sociólogo Reginaldo Prandi destaca o importante papel do sincretismo afro-brasileiro nesse contexto de resgate das tradições africanas e de adaptação do candomblé e de outras religiões originárias daquele continente à realidade do Brasil.

O sincretismo foi um mecanismo cultural decisivo para a reconstituição das religiões africanas no Brasil. A própria palavra "santo" serviu de tradução para "orixá", inclusive nos termos "mãe de santo", "filho de santo", "povo de santo" e outras palavras compostas em que originalmente a palavra africana era orixá. E esse santo é o santo católico (PRANDI, 2009, p. 50).

Assim, os chamados "filhos" ou "filhas" de santo são os sacerdotes dos orixás e têm como função reencarná-los durante as cerimônias religiosas do candomblé. Já os orixás são as divindades cultuadas pelos povos iorubá (ou nagô), originários das atuais regiões da Nigéria e Benin (ex-Daomé) que, além do idioma em comum, estão unidos por uma mesma cultura e tradições. Parte, portanto, de um sistema cultural e religioso, os orixás são os deuses protetores dos seres humanos, recebendo destes, homenagens e tendo uma simbologia segundo a qual cada um está associado a um elemento da natureza. 
Salvador foi a primeira capital da colônia e sediou um grande porto histórico no comércio de escravos que ali chegavam em navios negreiros vindos de diferentes partes da África. Embora constata-se na Bahia, desde muito cedo, ainda no século XVI, a presença de negros bantu, originários dos atuais territórios de Angola e Congo, foi a chegada de um contingente numeroso de africanos "sudaneses", provenientes de regiões habitadas pelos daomeanos (gêges) e pelos iorubás (nagôs) que tiveram o modelo de seus rituais de adoração aos deuses adotado por outras etnias já instaladas ali, onde estes últimos exerceram, de maneira mais forte, a sua influência cultural sobre os outros grupos (VERGER, 2002, p. 23).

Uma vez contextualizado, ainda que muito brevemente, a chegada dos negros e as suas crenças em Salvador, voltemos ao livro Bahia, no qual Mario Cravo Neto, buscando traduzir a complexidade do sincretismo que ali se deu, reuniu, na sequência de suas páginas, fotografias de igrejas e de cultos do candomblé, o que mostra a diversidade de elementos religiosos e culturais os quais compõem a realidade particular da cidade. Além dos registros das paisagens da capital nas quais as imensas igrejas se sobrepõem ao casario antigo e decadente (Fig. 16) e das suas fachadas exuberantes (Fig. 17), Cravo Neto, aparentemente ignorando os momentos das missas repletas de cristãos, concentra o seu olhar nos detalhes dessas edificações católicas que demonstram não exatamente a fé cristã do povo baiano, mas, sobretudo, a opulência típica dessa religião representada pela riqueza e suntuosidade de sua arquitetura e decoração com peças, por vezes, banhadas a ouro (Fig. 21). 
Figura 16 - Mario Cravo Neto. Santo Antônio além do Carmo, Pelourinho, 1979.

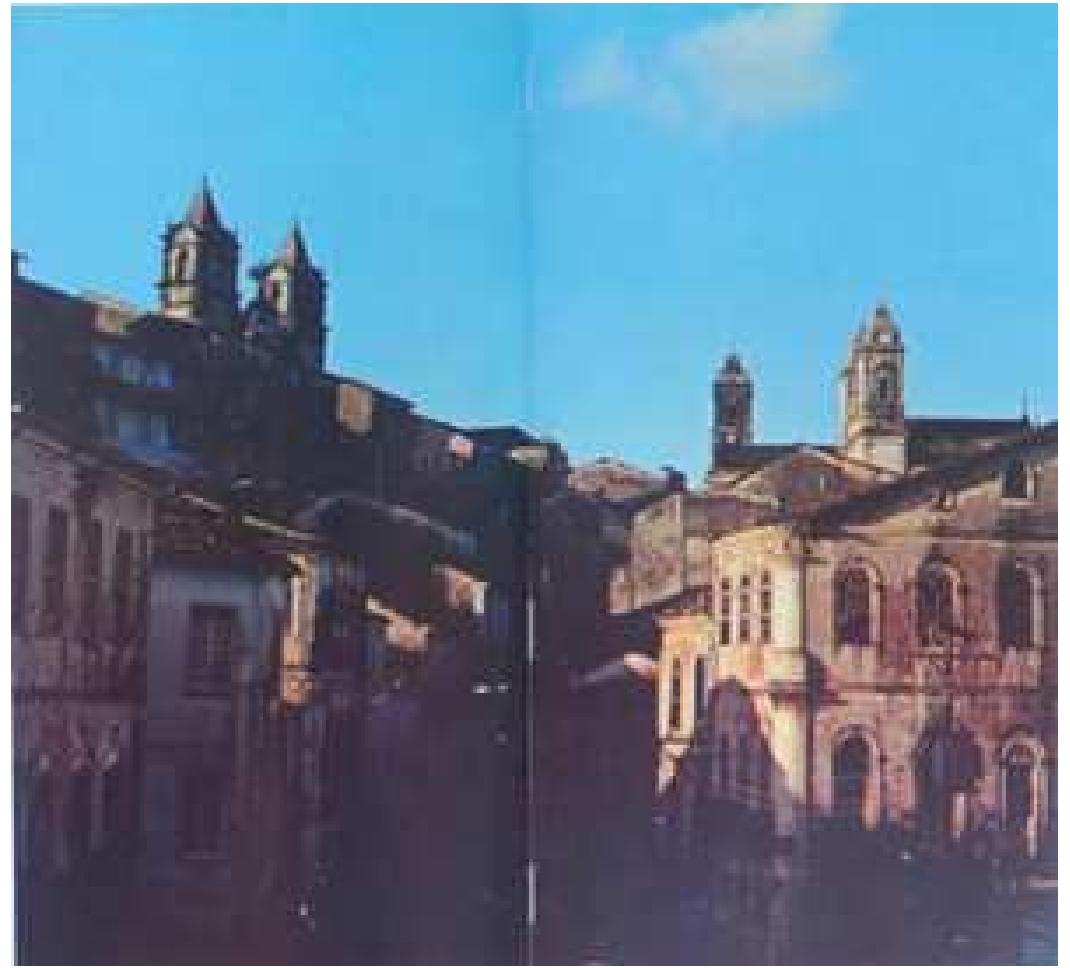

Fonte: Cravo Neto (1980).

Figura 17 - Mario Cravo Neto. Fachada de Ordem Terceira e da Igreja de São Francisco, Pelourinho, 1975.

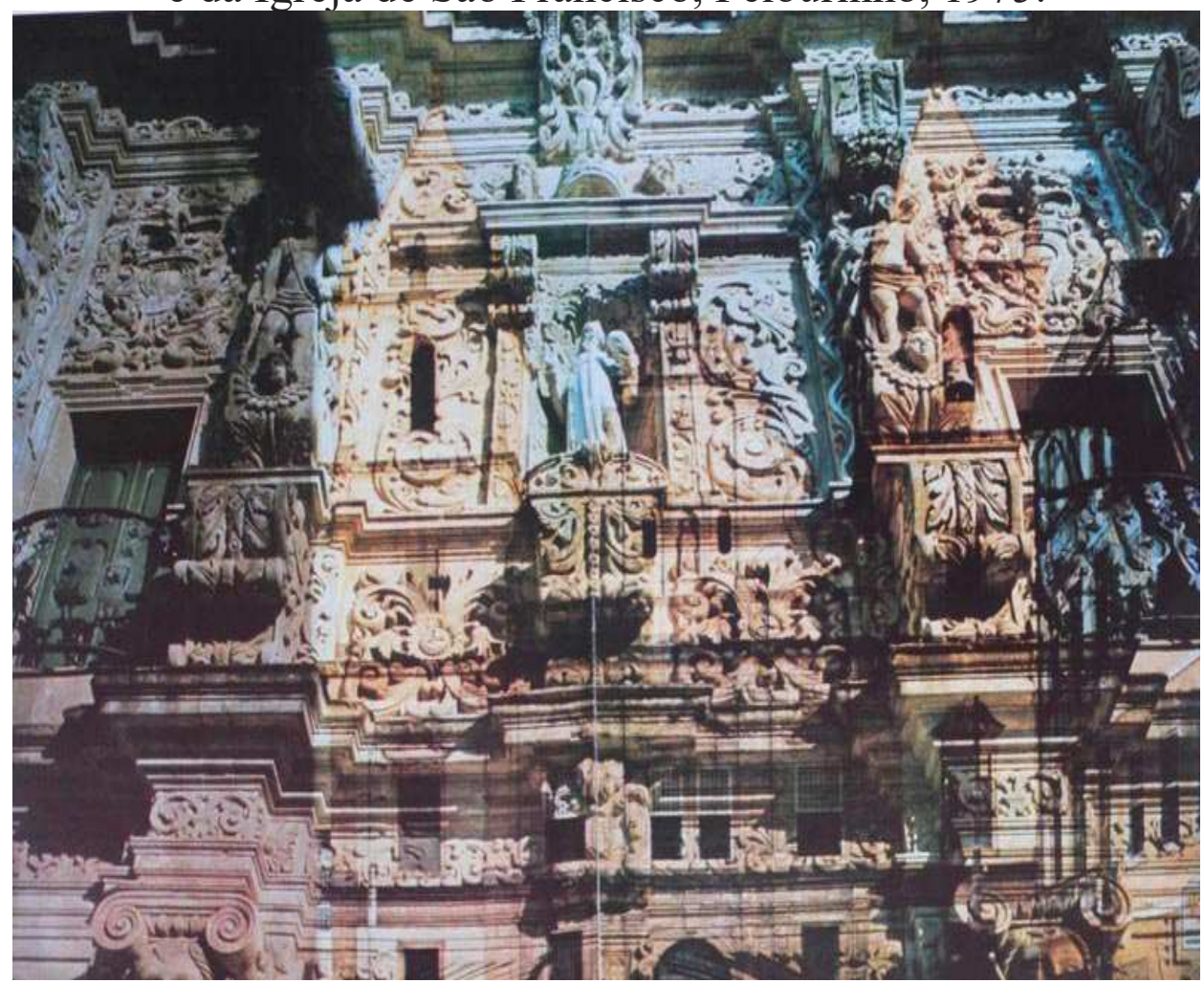

Fonte: Cravo Neto (1980). 
Diante da realidade sincrética em Salvador, Cravo Neto, além das múltiplas igrejas da cidade, não deixaria de trazer nas páginas de seu livro alguns elementos do rico universo da cultura africana que tanto contribuiu para a formação religiosa de sua terra. E o fotógrafo o fez por meio de fotografias dos terreiros de candomblé que entram literalmente na narrativa visual de Bahia como uma continuação africanizada dos templos católicos. Ainda que sejam poucas, se comparadas ao total de imagens do livro, as fotografias dos terreiros representam de maneira inusitada e poética esta religião, como podemos notar nas figuras abaixo.

Figura 18 - Mario Cravo Neto. Candomblé, Itapuã, 1980.

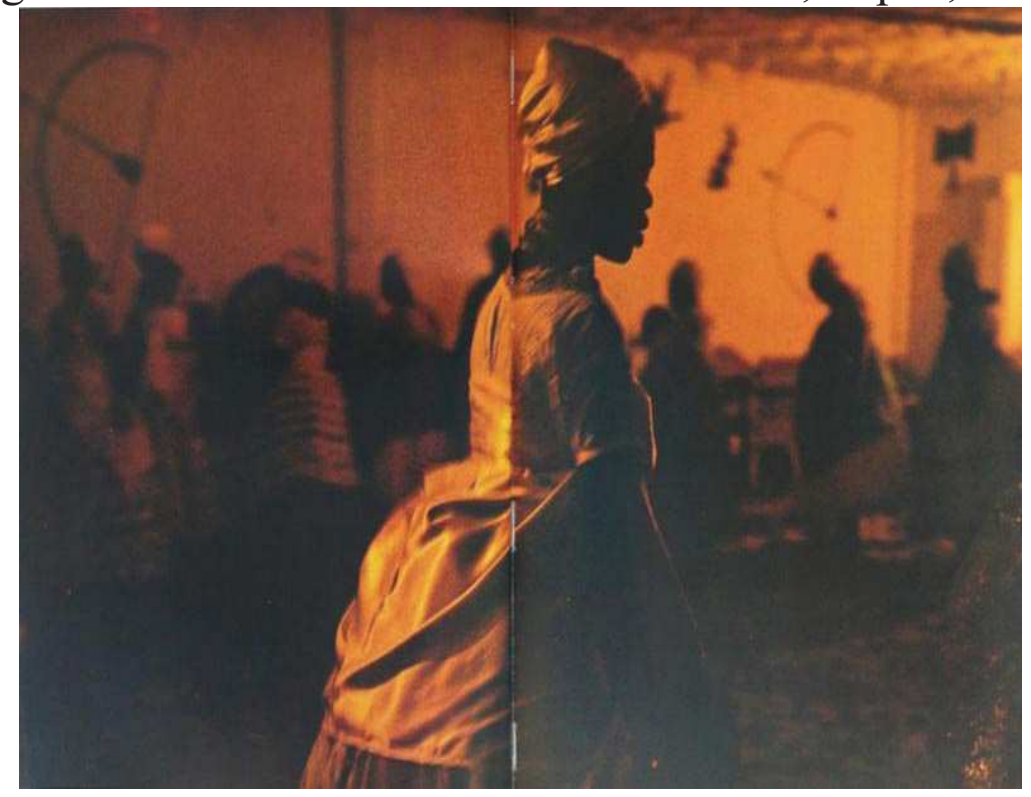

Fonte: Cravo Neto (1980). 
Figura 19 - Mario Cravo Neto. Filhas de santo, São Lázaro, 1974.

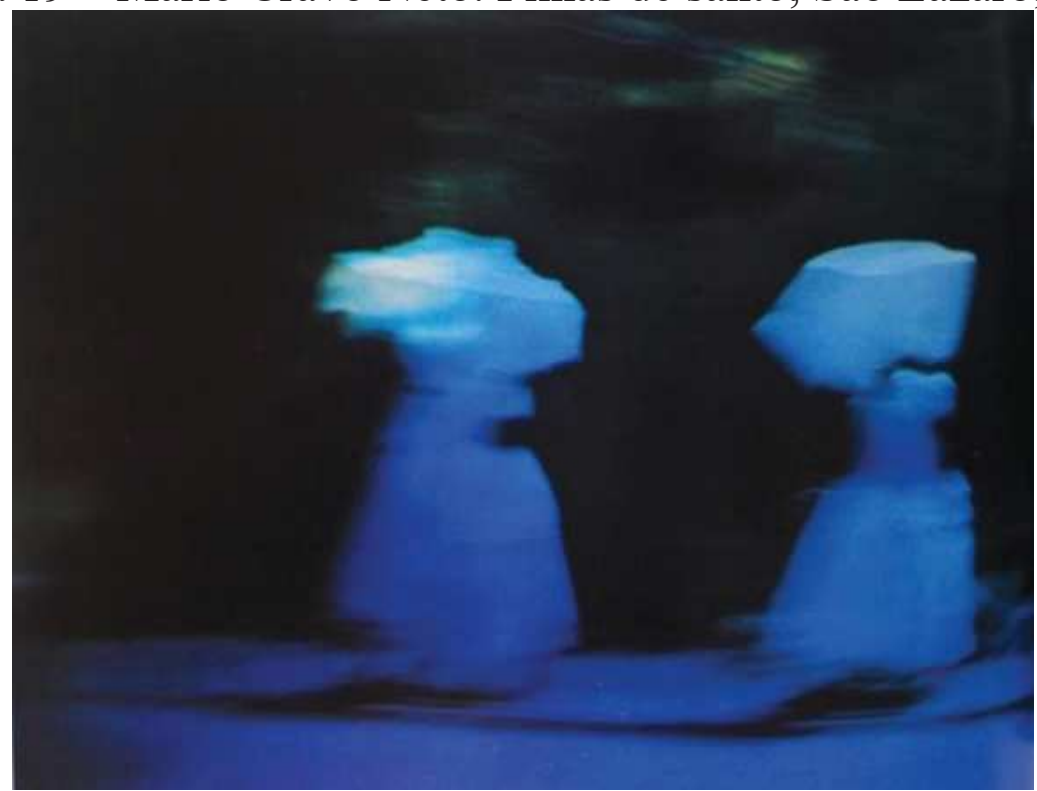

Fonte: Cravo Neto (1980).

$\mathrm{Na}$ fotografia da esquerda, vemos um grupo de filhas de santo dançando durante uma cerimônia de candomblé realizada em um terreiro no bairro de Itapuã. Nessas festas públicas, conhecidas como xirês, os orixás, que vivem no orun (o céu, o mundo imaterial ou sobrenatural), são chamados ao ayê (a terra, o mundo físico dos homens), não apenas por meio dos tambores tocados pelos alabês, mas também por meio dos cânticos e danças das iaôs (filhas de santo), cujos gestos e palavras extraídas dos mitos iorubás rememoram certos episódios da história dessas divindades. Como o mito deve ser simultaneamente falado e representado, a força das imitações miméticas e o encantamento das palavras relacionadas aos orixás evocados fazem com que estas, então, não tardem a "baixar" e possuir o corpo das iaôs (BASTIDE, 1978). Portanto, além do aspecto místico desse culto, no qual várias divindades são cultuadas, a sensualidade também se mostra no rico vestuário das filhas de santo - como observamos nesta em primeiro plano e ao centro da imagem 
- e também na dança de todas elas. As fotografadas em silhueta não só são um efeito que acentua o clima de mistério do terreiro como dá contornos e espaço para a insinuação do oculto, de espíritos nos médiuns incorporados. Vai assim inserindo uma outra camada de sentido em cada foto.

Já na fotografia da direita, Cravo Neto se utiliza, mais uma vez, da baixa velocidade do obturador da câmera para registrar duas filhas de santo que surgem como espíritos vagando por uma estrada à margem de uma mata fechada. Se, do ponto de vista técnico, esta longa exposição do filme supre a fraca iluminação (lunar ou de um poste, talvez) que recai sobre as filhas de santo, do ponto de vista estético, tal recurso as transforma em uma espécie de entidades sobrenaturais, já que, na imagem, elas parecem flutuar como vultos borrados e azulados devido, respectivamente, ao seu movimento e ao provável uso de um filtro dessa cor. Nessa nova camada de sentido o que não se vê na foto flagrante ganha desenho na composição entre a ação captada pela câmera e a técnica que altera a forma do objeto.

Essas inusitadas formas de representação adotadas, sobretudo, nas fotografias do candomblé diferem das da maioria das imagens do livro e sugerem que Mario Cravo Neto, desde os anos 1970, já estava - ainda que de maneira embrionária - não apenas refletindo especificamente sobre o enigmático universo animista do culto aos orixás, ${ }^{4}$ mas também buscando uma linguagem poética para documentá-lo. Elas indicam que, desde essa época, Cravo Neto vinha experimentando a linguagem fotográfica a fim de, a partir dos 4 De acordo com Prandi (2005), o culto aos orixás, em seus primórdios, manifestava-se por meio do animismo. Os antigos iorubás cultuavam o sol, a lua, as estrelas, os rios, os mares, montanhas, florestas, rochas, plantas e a chuva. Havia a crença de que todas as coisas tinham vida como os próprios seres humanos. 
ritos do candomblé e da mitologia dos orixás, materializar os seus aspectos espirituais, ou melhor, responder à seguinte questão: “como extrair o visível do inominável", como bem observou Herkenhoff (2009), referindo-se à "indagação perene do artista".

Em suma, essas fotografias, ainda que sejam minoria, tanto destoam esteticamente das demais apresentadas no livro, quanto escapam ao tradicional conceito de "fotografia documental" enquanto gênero fotográfico, inventado no século $\mathrm{XX}$, cujas imagens se prestariam à representação realista do mundo. Embora as sequências compostas no livro recorram a uma estrutura narrativa documental.

\section{Considerações Finais}

É inevitável perceber a poética com expressão de fundo, interior no registro de Cravo Neto em cada quadro que captura Salvador e suas idiossincrasias nas quais o belo e o cru de uma realidade de desigualdade, descriminação encontra sua resiliência e sobrevive nos costumes, nas práticas religiosas e gastronômicas e numa espiritualidade que opera na permanente fronteira do sacro e do pagão, da religião branca, europeia e os rituais e crenças ancestrais africanas. Esses sutis movimentos entre a poética e a realidade vão construindo a crítica social do fotógrafo. A lente de Cravo Neto compreende que o sujeito da ação é primeiro na narrativa documental, mas expressa claramente que o contexto e o espaço da cena são imprescindíveis para a construção de sentido. Virgem Maria e Iemanjá se amalgamam na invocação do sagrado feminino que cuida do mar e dos pescadores e suas famílias.

O olhar de Cravo Neto observou e captou o excluído, o 
sujeito social e econômico fora da estatística formal. Ao privilegiar o quadro de feirantes, ambulantes, pequenos comerciantes, sacerdotes do candomblé e meninos de rua falou de uma Salvador real, da população viva da cidade. Gente que retrata o cotidiano, o pulsar, a energia mais interior e plena daquela população e comunidade baiana.

Nessa escolha documental não abona o diálogo com a tradição dos fotógrafos pioneiros da corrente reformista da "Fotografia Social" e aproxima-se sim do fotojornalismo engajado do século XX, mas com um peculiar cuidado para não estetizar o sofrimento ou o exótico. Suas lentes não querem chocar, desejam convidar o olhar ao pensamento, à reflexão. O pobre, o afro-descente, o batuqueiro não são vítimas que requerem piedade. Nos registros de Mario Cravo Neto, eles são atores sociais que transcendem a tudo: esquecimento, abandono, invisibilidade e estranhamento. Não são peças exóticas do folclore de um país tropical, são gente.

Não há romance, não há denúncia. Os personagens de Cravo Neto operam instrumentos de superação à opressão e à violência. E esse traço aparece também nos registros de objetos que não são aleatórios. Produzem construções de sentido sobre os sujeitos que estão por trás daquela cena. São os registros figurativos de teor catalográficos dos utensílios domésticos, das frutas, dos produtos típicos da região, como vimos presentes especialmente na tradicional Feira de São Joaquim. Ou nas fotografias de bancas de venda de miudezas, quinquilharias e produtos variados. Ou ainda nas vendedoras de acarajé.

Ao documentar as belezas e mazelas naturais e humanas da sua cidade, Cravo Neto traz a cena um lirismo singular, especialmente 
na exposição do sincretismo visível nas Igrejas e nos terreiros de Candomblé, combinando, em alguns casos, baixa velocidade de obturador e movimento da câmera para produzir imagens borradas e tremidas que destoam da maioria dos registros objetivos deste livro.

Finalmente, cabe ainda ressaltar que Cravo Neto insere em sua atitude experimental um componente ético essencial e muito tradicional no campo da documentação: o engajamento por meio de um olhar crítico sobre a realidade e os processos de marginalização de determinados grupos sociais que, em suas imagens, são representados em estado de altivez e resistência, mesmo sendo historicamente estigmatizados e vivendo em constante situação de ameaça e opressão. Há, não apenas neste livro, mas em todos os seus trabalhos, a busca por uma identidade nacional que faça frente à superficialidade do olhar que torna o sujeito fora do padrão do colonizador europeu em algo exótico.

Diante de uma complexa história de formação da sociedade brasileira e seu passado colonial, compreende-se que Cravo Neto entendeu necessário representar o sujeito livre não apenas de uma visão externa e, por vezes, estereotipada pelos viajantes do século XIX, ou por meio de uma linguagem objetiva e realista como a utilizada, em geral, pela imprensa internacional e brasileira nos seus registros dos dramas sociais e da violência do país. Captou o sujeito com o auxílio da câmera fotográfica buscando uma conversa entre a cena crua e o olhar poético de quem percebe os sujeitos fotografados tais como são na sua beleza mais pura.

Por fim, Cravo Neto parece mesmo inaugurar uma relação dialética entre o documentário objetivo e uma narrativa documental subjetiva na qual sua escolha estética está para além da camada do 
152 Belezas e mazelas naturais e humanas nas fotografias do livro Bahia de Mario Cravo Neto

flagrante. Inscreve-se em outros níveis de sentido que se expressam além e no interior dos objetos fotografados.

\section{Referências}

AMADO, Jorge. Bahia de todos os santos: guia das ruas e dos mistérios de Salvador. 19. ed. São Paulo: Martins, 1970.

AMADO, Jorge. Canto de amor à Bahia. In: CRAVO NETO, Mario. Bahia. Salvador: Raízes, 1980.

BASTIDE, Roger. O candomblé na Bahia: rito nagô. 2. ed. São Paulo: Nacional, 1978.

BRILL, Stefania. Mario Cravo Neto: poeta e escultor da luz. Revista Iris Foto, Osasco, SP, n. 393, p. 24-31, jun. 1986.

CAMARGO, Denise Conceição Ferraz de. Imagética do candomblé: uma criação no espaço mítico-ritual. 2010. Tese (Doutorado em Artes) - Universidade Estadual de Campinas, SP, Campinas, 2010.

CARNEIRO, Edison. Candomblés da Bahia. 5. ed. Rio de Janeiro: Editora Civilização Brasileira, 1977.

CRAVO NETO, Mario. Bahia. Salvador: Raízes, 1980.

CRAVO NETO, Mario. Butterflies and zebras. São Paulo: Pinacoteca do Estado, 2013.

CRAVO NETO, Mario. Laróyè. Salvador: Áries, 2000.

CRAVO NETO, Mario. Mario Cravo Neto. Salvador: Áries, 1995.

CRAVO NETO, Mario. O tigre do Dahomey: a serpente de 
Whydah. Salvador: Áries, 2004.

CRAVO NETO, Mario. The eternal now. Salvador: Áries, 2002.

CRETELLA, Clarissa Coimbra de. A Bahia tem um jeito que nenhuma terra tem. In: CRAVO NETO, Mario. Bahia. Salvador: Raízes, 1980.

HERKENHOFF, Paulo. A espessura da luz: fotografia brasileira contemporânea. São Paulo: Câmara Brasileira do Livro, 1994. Brasil: Confluência de Culturas - $46^{\text {a }}$ Feira do Livro de Frankfurt, 1994.

HERKENHOFF, Paulo. Eternamente agora: tributo a Mario Cravo Neto. Exposição: Eternamente agora. Tributo a Mario Cravo Neto. Curadoria: Paulo Herkenhoff e Christian Cravo. São Paulo: Instituto Tomie Ohtake, 2009. Catálogo da exposição.

TRACHTENBERG, Alan. Social Photography: Lewis W. Hine (1874-1940). In: TRACHTENBERG, Alan (ed.). Classic essays on photography. New Haven: Leete's Island Books, 1980. Part three: Modern currents: social photography, Lewis Hine, p. 109-114.

PRANDI, Reginaldo. Religião e sincretismo em Jorge Amado. In: SCHWARCZ, Lilia Mortitz; GOLDSTEIN, Ilana Seltzer (org.). O universo de Jorge Amado. São Paulo: Companhia das Letras, 2009. v. 1, p. 46-61.

PRANDI, Reginaldo. Segredos guardados: orixás na alma brasileira. São Paulo: Companhia das Letras, 2005.

VERGER, Pierre. Orixás: deuses iorubas na África e no Novo Mundo. 6. ed. Salvador: Corrupio, 2002. 